\title{
USE OF TIME IN SINGLE-MEMBER HOUSEHOLDS IN SLOVAKIA
}

\author{
Miroslava Knapková, Alena Kaščáková
}

\section{Introduction}

Households represent one of the economic subjects entering to the market mechanism. The microeconomic theory focuses on households mostly as units of consumption, savings, partly as production units. Households participate on the side of the supply as well as on the side of the demand (Samuelson \& Nordhaus, 2013; Mankiw, 1999). Households' specific status on the supply side arises from the fact that households offer their ability to work at the labour market. When considering households on the demand side, mostly demand for goods and services that satisfied households' needs must be included. Single-member households is a specific group of households. Their amount in the world has risen significantly in the last decades. Particularities of single-member households are linked with demography, sociology, relationships, economy, as well as with specific allocation of their time. The aim of this study is to examine the use of time of single-member households in Slovakia. We analysed 301 single-member households and allocation of their daily time into 13 activities. Results of this study are based on original primary research (so far, there was no official time use survey in Slovakia). The use of time of households does not belong to the standard topics of microeconomic theories, however, it influences, and it is closely linked with specifics of the households' consumption, savings, participation on labour market, production (market production as well as non-market production in case of unpaid work performed in households) and other aspects covering by microeconomic theories.

\section{Theoretical Framework of Research} Households as economic subjects are very dynamic. Number of households and structure of households according to the number of members, as well as households' economy, division of the time and spending of the time are changing quite often. Many changes in households' behaviour and households' structure correspond with the general changes in the society. Changes in the reproduction behaviours in the last period lead to the decreasing of the households' members number and decreasing of the ratio of the traditional and complete families. Young persons postpone time for concluding matrimony and they prefer to fulfil their individual goals and values. Traditional matrimony is replaced by various types of alternative relationships (Roseneil \& Budgeon, 2004; Kaufmann 1999). This is an international phenomenon and many researches have confirmed that number of households permanently increases (as a consequence of decreasing of the households' members number) in most of the developed countries (Williams, 2003; Wulff, 2001). Attitudes towards individual's privacy have changed significantly in the last decade. Privacy is being considered as one of the inalienable human rights (Klinenberg, 2012; Singly, 2009). Individual ownership (mostly in case of housing ownership) leads to the increasing independence from the family. Mostly in the age of emerging adulthood, individuals have many possibilities for personal self-realization outside the families. This can lead to the continuous living in the singlemember household.

Living in the single-member households is becoming evident mostly in the developed western countries. According to Hooper et al. (1998), decreasing number of household's members is evident in those countries, which are in the post-industrial stage of their development. Living alone is not a completely new phenomenon and even in the past there 
was a part of the population living alone. However, current worldwide situation is specific because of the growing ratio of population living alone. In 2006, there were more than 200 million single-member households in the world. It represents an increase of almost 50 million comparing to the previous decade (Hodgson, 2007). In his study, Hodgson (2007) also predict that in 2020, there will be more than 253 million single-member households in the world.

There are several studies concerning the changes in the households' structure also in the non-western countries. In Korea, ratio of singlemember household has increased rapidly from $9 \%$ in 1990 to $23.9 \%$ in 2010 and it is expected to continue to increase in the future (Jin-woong Son et al., 2016). Wang (2006) suggested three new types of households in China: the relatively stable type (e.g., three-generation immediate family), the obviously increasing type (e.g., single-member household, one-couple household, generation-skipping household), and the decreasing type (e.g., impaired nuclear family). According to data from last China censuses in 2000 and 2010, the percentage of two generation households dropped by $10 \%$ from 2000 to 2010 , while the proportion of onegeneration households increased by $11 \%$ in the same period. The only-couple households and single-member households were the dominant types of one-generation households. This shows that in accordance with the continuation of low fertility, the advancement of urbanization, improvement of housing conditions, and changes in family values, an increasing number of large families split into small families. Young people are becoming more independent (Zhan $\mathrm{Hu} \&$ Xizhe Peng, 2015). Growing number of single-member households is evident also in South Africa. Amoateng et al. pointed out the changes in the living arrangements in South Africa between 1996 and 2001. They noted an increase in the number of single-member households (which are more closely associated with 'Western' norms) but also noted the continued relevance of complex household types (Wittenberg et al., 2017).

Single-member households take an important part of the consumer market. They significantly influence consumer market growth, because they deserve the same home equipment as multiple-members households as well as specific goods and services linked with their specific status. Marketers focus mostly on the group of "singles" and in the last years also on the group of retired people living in single-member households (Klinenberg, 2012). Hawk (2011) pointed out that single-member households (particularly "singles") consume standard market products (however, in smaller quantities comparing to married couples and multi-persons households), but also specific products and services. They are willing to invest significant part of their incomes in the selfimprovement, education, and entertainment. According to the data of the Bureau of Labor Statistics (https://stats.bls.gov), single-member households become the fastest growing group of the consumers in the United States of America. Only in the USA, single-member households spend almost 1.9 billion US dollars (it is almost one third of all expenditures of all households in the USA). A person in singlemember household spend in average 6,000 US dollars per year more than a person in marriage couple, and 11,000 US dollars per year more than a person in family household (https://stats. bls.gov).

A particular group of single-member households represents "singles“. Singles phenomena and their living in the singlemember households is linked with the process of the individualization of the society (Jamieson \& Simpson, 2013; Beck \& Beck-Gernsheim, 2002). Singles usually prefer individual freedoms and values to social and family obligations (Poortman \& Liefbroer, 2010). Singles are also noted by specific attitude towards the work. Work is not only place to earn money for them, but also place for social interactions and tool of self-realization. Jamieson and Simpsons (2013) focused more on the specific role of the work for singles. Singles used to perform paid work also in their free time and it is difficult to distinguish time for paid work and free time in their case (Dudová, 2008; Jamieson \& Simpsons, 2013). Allocation of the time and time use is specific not only in "singles" group, but in the whole group of persons living alone in single-member households.

There are several possibilities of collecting data on how individuals spend their time. Sociologists and economists, for example, prefer self-kept time diaries, anthropologists focus more on observation and some studies are based on stylized approach. However, many researchers consider time diary approach the most accurate. As Robinson and Godbey 
(1997) stated, administered time-diary study is necessary to accurately measure time spent on various activities. The diary procedure avoids the problems of a time estimation and prevents respondents from purposefully distorting activity estimates. Bittman and Wajcman (2000) also argued, that stylized questions (stylized approach) produce less accurate results than a full diary. Comparison of diary information and questionnaire information about the paid work and unpaid work was included in the study of Bonke (2005). He confirmed that labor supply studies based on questionnaire-information are less accurate than studies based on diary information. Budlender (2010) focused on the relation between the unpaid care work and time use. Study included eight countries - Argentina, Nicaragua, India, Republic of Korea, South Africa, Tanzania, Switzerland, and Japan. In each country, researchers analysed official time use survey data. In five countries, time diary approach was used. In rest of countries, stylized approach (questions related to specific activities) was used.

One of the method of diary time collection, is time use survey. Time use survey (further in the text only TUS) is a statistical survey which aims to report data on how people spend their time (In: Zist'ovanie o využívaní času). In 1972 , team of researchers published study on daily time use in twelve countries - Belgium, Bulgaria, Czechoslovakia, Federal Republic of Germany, France, German Democratic Republic, Hungary, Peru, Poland, USA, USSR, Yugoslavia. Their study was based on time budget analysis, where time budget is a "block" of time (an aggregate amount of hours and minutes) which represents the per capita average of the total daily time expenditure on a specific kind of activity. All blocks (sum of each items on the daily agenda of people) add up to 24 hours or 1,440 minutes per day (Szalai et al., 1972).

In many countries, official time use surveys are used. Since 1990 to 2013, sixty-nine countries worldwide conducted a time use survey (In: Guidelines for Harmonising Time Use Surveys). In fifteen European countries, the harmonized European time use surveys (HETUS) is used from 2000. According to "Zist'ovanie o využívaní času“, the TUS survey was realized in Australia (in 1992, 1997, 2006), in Finland (every ten years starting from 1979), in France (in 1966, 1974/1975, 1985/1986,
1998/1999, and in 2009/2010), in Greece (in 2013/2014), in Germany (in 1991/1992, 2001/2002, and in 2012/2013), in New Zealand (in 1998/1999 and 2009/2010), in Poland (in 1968, 1976, 1984, 2003/2004 and in 2013), in Austria (in 1981, 1992 and in 2008/2009), in Italy (in 2002/2003, 2008/2009, and in 2013/2014), in Spain (in 2002/2003 and in 2009/2010), in Sweden (in 1990/1991, 2010/2011, and in 2010/2011), and in Great Britain (in 2000/2001 and in 2014/2015).

In Slovakia, there was only one TUS in 2006 (launched as a pilot survey), without no consequence continuation. From 2012, multidisciplinary team of researchers at the Faculty of Economics, Matej Bel University, has launched six field researches. However, in first five of them we focused particularly on time dedicated for unpaid work, eventually unpaid work, and paid work. In the last field research from 2017, we summed up, for the first-time, overall time use of households and individuals, by using time diary approach.

In the last years, several studies focused on specific groups of activities within the time use and specific consequences of the time use. In 2011, Seybert (2011) published study on internet use in households and by individuals. Internet use and interpersonal relations were analysed based on time diary in the study of Nie et al. (2002). Bittman and Wajcman (2000) focused on leisure time of men and women in Australia. Nässén and Larsson (2015) analysed time use of households in the relation with the consumption in Sweden. Time use of households is analysed often in relation with environmental issues (e.g. Bruvoll et al., 2002; Kitamura, 1997; Widén et al., 2009). Time use is also used in relation with the children care (e.g. Hill \& Stafford, 1980; Kalenkoski et al., 2005; Craig, 2006) and unpaid work in general (e.g. Budlender, 2010; Hook, 2006; SevillaSanz, 2010). Time use theories and empirical studies are often linked with gender inequality and role of women in the family.

Many researchers have focused on the time use from the families' point of view (e.g. Lewis \& Cooper, 2005; Greenhaus \& Singh, 2003) and from the work-family or work-life point of view. When both parents work (or when considering single-parent family), it is difficult to balance work, housekeeping, and children care. In their study, Emslie and Hunt (2008) elaborated extensive literature review on time use and 
work - life balance and conflict according to gender. In the monograph Neplatená práca na Slovensku (Uramová \& Orviská et al., 2016), gender inequality in performing unpaid work in Slovak households is analysed. Bailyn et al. (2001) stated that many working adults, particularly single parents, and those in dualearner families, have difficulty providing the ordinary daily attention needed for the well-being of family members, including themselves. Time to care for children, as well as for the increasing population of aging relatives, is becoming a serious concern. Caproni (1997) focused on balance in a two-career family with two children under the age of four years. In their study, Hill et al. (2001) analysed job flexibility in relation to the improved work-family balance after controlling for paid work hours, unpaid domestic labour hours, gender, marital status, and occupational level. According to them, flexibility appears to be beneficial both to individuals and to businesses. Correlation between the gender and flexible working conditions as aspects of the work-life balance is elaborated in the study of Smithson and Stokoe (2005).

Only few studies have focused on time use of persons living alone (in single-member households). Living alone in single-member household means living out of traditional family. Persons living alone do not care children on daily base (living alone does not mean that person does not have children, but children do not live with this person in a common household).

In their study, Aguiar et al. (2013) compared time use of married couples and singles. They stressed an importance of considering specific population groups, such as married people compared to singles, mostly regarding the extent of unpaid domestic work. They reported larger increases in unpaid domestic work for married people compared to singles. For example, among married couples, the increase in unpaid domestic work including child caregiving accounts for $42 \%$ of the loss in paid work hours, compared to 16 percent for single people.

\section{Research Methodology}

To analyse time use of particular groups of individuals or households, it is important to understand quantitative and qualitative aspects of the research problem. We must focus not only on the preferences, attitudes and opinions about the structure and distribution of day activities, but also on the extent of the time that individuals spend by performing paid work, unpaid work in the households, and leisure time activities. Besides other factors, mostly sociodemographic features of the individuals and their households influence allocation of the time between the paid work, unpaid work, and free time. We can analyse different sources of information to get appropriate data on time use of single-member households.

\subsection{Potential Data Sources}

The most relevant source of information about the allocation of the time is Time Use Survey. In several countries, TUS is realised from the level of the national statistical bureau; in Slovakia, however, there has not been TUS survey realised yet (except the pilot survey in 2006). To estimate volume of the time that individuals and households spend by performing certain activities, we can use also selected questions from the questionnaire survey of the International Social Survey Programme (ISSP), module "Family", (Slovakia was included in the ISSP survey in 2012), from the European Quality of Life Survey (EQLS) surveys, and from the Eurobarometer surveys. In Slovakia, two surveys focusing on the gender division and allocation of time in the households were launched. Organisation Alliance of Women in Slovakia, by the means of FOCUS agency, realised surveys in the first half of $90^{\text {th }}$ of the previous century. The second survey was realised by the Institute for Public Affairs in August 2006. Questionnaire survey of the European Social Survey, Round 5 (Slovakia was included in this survey in 2010) included also several questions regarding the time use of individuals and households.

Above mentioned sources of information allow us to analyse time use of the Slovak households and extent of time dedicated to various activities only partially and marginally. This information does not cover the whole structure and volume of the time use and does not include data on seasonal activities. Even more, there is no any official data source from the Slovak Statistical office neither from the European surveys.

\subsection{Research and Data}

To analyse time use of the single-member households in Slovakia, we used data from the original field research. Multidisciplinary team 
of researchers conducted the field research based on diary time collection in 2017, within the VEGA project "Decision-making of Slovak households about time allocation for paid and unpaid work and effect of household strategies on selected areas of the economy". The aim of the research was to collect data on daily time use of individuals and households and to identify opinions, preferences, and attitudes of respondents towards the allocation of the time in paid and unpaid activities. We surveyed Slovak households and individuals by the means of questionnaire survey. Modules focusing on the attitudes of respondents, sociodemographic profile of respondent including household composition and diary collecting data on performed activities during the day were included in the questionnaire.

To identify groups of activities performing during the day, we draw from the HETUS 2008 classification (European Communities, 2009). In the HETUS classification, there are ten fundamental groups of activities: personal care, employment, study, household and family care, voluntary work and meeting, social life and entertainment, sports and outdoor activities, hobbies and computing, mass media, travel, and unspecified time use. Fundamental groups are divided in three, more detailed levels. For our project and research, we selected thirteen groups of activities from all available groups and sub-groups. We maintained the original fundamental classification of HETUS and we divided group "household and family care" into three sub-groups: housekeeping, childcare and help to an adult household member; and group "personal care" into two sub-groups: sleeping and personal care.

Our survey was conducted in March 2017 and we questioned 833 households and 1,767 individuals (members of the households) in Slovakia. We used CAPI (Computer Assisted Personal Interview) method to record answers of respondents. Afterwards, we recode all answers and prepare data for further proceedings. We divided all acquired data into two databases - database of answers from households and database of answers from individuals. After weighing all data, we confirmed representativeness of the sample by the number of household members and by the region (database of households) and by the age and sex (database of individuals). For this article, we exported and analysed data on single-member households. We used SPSS software, version 19, to test hypothesis (we used significance level 0.05).

\subsection{Aim of the Study and the Time Use}

The aim of this study is to examine the time use of single-member households in Slovakia. We focused on single-member households because they represent continually growing group of households in Slovakia. We analysed 301 single-member households and allocation of their daily time into 13 activities: sleeping, personal care, travelling, paid work, study and self-study, housekeeping, children care, adults care, free time, cultural and social activities, sport, usage of modern technologies, voluntary activities. We divided daily time (24 hours, or 1,440 minutes) into three groups of activities - sleeping, work and life. "Work“ includes paid work and travelling. Paid work involves dependent work performed by employee for employer (in Slovakia, maximum weekly working time is 40 hours, it means 8 hours in average per day; however, it is possible to conclude more parallel employment contracts), independent work of entrepreneur (in our research, we consider only entrepreneur natural person), and various kinds of paid activities according to private law contracts. "Life“ (or private life) includes personal care, study and self-study, housekeeping, children care, adults care, free time, cultural and social activities, sport, usage of modern technologies, voluntary activities.

To get information about the daily time use of persons, we used household member diary. Besides collecting data on time use, we also collected information about the attitudes and preferences of individuals concerning the paid work and unpaid work (attitudes and preferences regarding the leisure time activities were not included in our survey).

\section{Single-Member Households in Slovakia}

Comparing results of six censuses from 1961 to 2011 , it is evident that ratio of single-member households increased significantly (from 18.1\% in 1980 to $25.7 \%$ in 2011 when considering economic households, and from $10.4 \%$ in 1961 to $29.5 \%$ in 2011 when considering census households). More detailed structure of economic households and census households in various censuses is displayed in Tab. 1. 


\begin{tabular}{|c|c|c|c|c|c|c|c|c|}
\hline Tab. 1: & \multicolumn{8}{|c|}{$\begin{array}{l}\text { Number and structure of individual household types by census in } \\
\text { (in 1961-2011) }\end{array}$} \\
\hline \multicolumn{3}{|c|}{ Year } & 1961 & 1970 & 1980 & 1991 & 2001 & 2011 \\
\hline \multicolumn{9}{|c|}{ Indicator } \\
\hline \multicolumn{3}{|c|}{$\begin{array}{l}\text { economic households } \\
\text { (in thousands) }\end{array}$} & & 1,267 & 1,585 & 1,778 & 1,900 & 1,852 \\
\hline \multirow{6}{*}{\multicolumn{2}{|c|}{$\begin{array}{l}\text { structure by number } \\
\text { of members }(\%)\end{array}$}} & 1 & & & 18.1 & 20.9 & 26.3 & 25.7 \\
\hline & & 2 & & & 21.7 & 22.9 & 21.5 & 21.7 \\
\hline & & 3 & & & 18.8 & 18.1 & 17.9 & 19.4 \\
\hline & & 4 & & & 23.3 & 23.4 & 20.8 & 18.8 \\
\hline & & 5 & & & 11.2 & 9.9 & 8.3 & 7.8 \\
\hline & & $6+$ & & & 6.9 & 4.8 & 5.2 & 6.6 \\
\hline \multicolumn{3}{|c|}{ census households (in thousands) } & 1,183 & 1,345 & 1,660 & 1,832 & 2,072 & 2,232 \\
\hline \multicolumn{3}{|c|}{ in that (in \%): complete families } & 81.2 & 78.5 & 70.6 & 67.4 & 56.4 & 52.4 \\
\hline \multicolumn{3}{|c|}{ single parent families } & 8.4 & 8.6 & 8.2 & 10.4 & 11.9 & 16.1 \\
\hline \multicolumn{3}{|c|}{ one person households } & 10.4 & 11.9 & 21.2 & 21.7 & 30.0 & 29.5 \\
\hline \multicolumn{3}{|c|}{ multi-person non-family household } & & & & 0.5 & 1.7 & 2.1 \\
\hline \multicolumn{3}{|c|}{ Average census household size } & 3.5 & 3.4 & 3.0 & 2.9 & 2.6 & 2.6 \\
\hline
\end{tabular}

Source: Statistical Yearbook 2003 and http://portal.statistics.sk/showdoc.do?docid=73572

According to the "Prognóza vývoja rodín a domácností na Slovensku do roku 2030", single-member household is a household where one natural person either lives alone in the flat (house) or lives in the flat (house) together with other persons or with another census household, but is economically independent, or lives in the flat (house) as a lessee. It is not easy to predict further trends of the singlemember households in Slovakia. Slovakia is being considered as a country with traditional family structure. However, it seems that singlemember households are becoming increasingly spread also in Slovakia. The most common reasons for the single-member households' existence in Slovakia are dissolution of the standard family, death of one partner (this is more common in a higher age; another partner is living without children) and divorce (it occurs mostly in the second part of the production age; divorced partner is living alone without children). Another important group of singlemember households represent single persons in a young age (source: Prognóza vývoja rodín a domácností na Slovensku do roku 2030). This is a specific group, because they live single, they are economically independent and there is a significantly high probability, that within few years they will establish a standard family. However, many single-member households in young age belong to "singles" group. Phenomenon of "singles" is becoming increasingly spread in Slovakia, and this group will remain as single-member households also in the future (Šprocha \& Bleha, 2015).

The previous population trends and development, high divorce rate and low marriage rate caused increasing of the singlemember households also in productive age. Mostly in the close future, single-member households in productive age will change to the single-member households in post-productive age. In the combination with the fast aging of the population in Slovakia, single-member households in post-productive age will become a significant group within the all single-member households (Šprocha et al., 2014). According to their prognosis, most of the Slovak households in 2030 will belong to single-member households. Among these households, group of "singles" (it means individuals who live alone and intend to live alone, without partner and children for the rest of their lives) will cover a significant part).

In the following part of the study, we summed up interesting findings from our field research, concerning the time use of single-member 
households. Our data correspond with the time, that individuals (in single-member households, member of household corresponds with an individual) spend by performing paid activities (dependent work of employee for employer, independent work of natural person - entrepreneur, paid activities according to business law and civil law contracts and other paid activities), unpaid work (or work performed in the own household or in other households), free time, other activities, and sleeping. For this analysis, we integrated all unpaid work activities into three groups - housekeeping, children care and adults care. Other activities (they are neither the part of unpaid work nor free time) include personal care, traveling, studying and self-studying, cultural and social activities, sport, usage of modern technologies and voluntary activities.

Besides comparing single-member households and multi-persons households, we also focused on two significant groups of singlemember households - "young" single-member households (individuals younger than 30 years of age) and "old" single-member households (individuals older than 65 years of age). We also analyse time use of single-member households by gender.

\section{Time Use of Single-Member Households}

Single-member households have many specifics comparing to multi-persons households. That is why we started our analysis of time use by comparing time use of singlemember households and time use of multiplemember households. There are also many specific features inside the group of singlemember households. We decided to focus deeper on differences and specifics by gender and age of persons living alone.

\begin{tabular}{|c|c|c|c|c|c|c|c|c|c|c|c|c|c|c|}
\hline & $\begin{array}{l}\text { Tin } \\
\text { (in }\end{array}$ & & sir & $\begin{array}{l}-\mathrm{m} \\
\mathrm{rk}\end{array}$ & $\begin{array}{l}\text { be } \\
\text { da }\end{array}$ & ous & olc & nd & ti & $\mathbf{S}$ & ho & h & & \\
\hline & $\begin{array}{l}\text { Number } \\
\text { of Household } \\
\text { Members }\end{array}$ & $\begin{array}{l}\frac{0}{\overline{0}} \\
\frac{\Phi}{\infty}\end{array}$ & 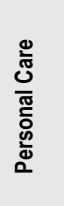 & 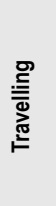 & $\begin{array}{l}\frac{1}{0} \\
3 \\
\frac{0}{\pi} \\
\frac{\pi}{2}\end{array}$ & 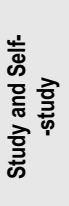 & 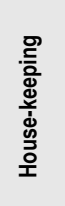 & 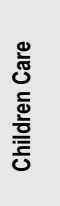 & 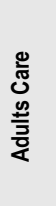 & 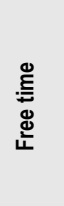 & 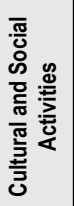 & $\begin{array}{l}\text { tํㅇ } \\
\text { ஸे }\end{array}$ & 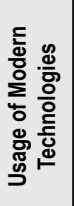 & 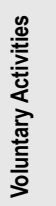 \\
\hline 1 & Mean & 485.6 & 113.3 & 43.5 & 401.4 & 7.3 & 90.2 & 3.8 & 0.2 & 160.1 & 41.6 & 43.7 & 45.4 & 1.2 \\
\hline 1 & Std. Deviation & 90.3 & 65.8 & 44.5 & 242.5 & 37.1 & 97.8 & 24.1 & 3.3 & 112.0 & 72.9 & 62.7 & 60.1 & 10.5 \\
\hline 2 & Mean & 474.3 & 98.0 & 47.0 & 369.6 & 62.9 & 100.2 & 39.1 & 2.9 & 150.5 & 19.2 & 29.3 & 39.6 & 0.6 \\
\hline $\mathrm{L}^{+}$ & Std. Deviation & 86.3 & 53.1 & 50.1 & 252.4 & 158.3 & 112.4 & 96.6 & 21.0 & 118.9 & 49.5 & 60.7 & 63.4 & 8.4 \\
\hline
\end{tabular}

Source: own

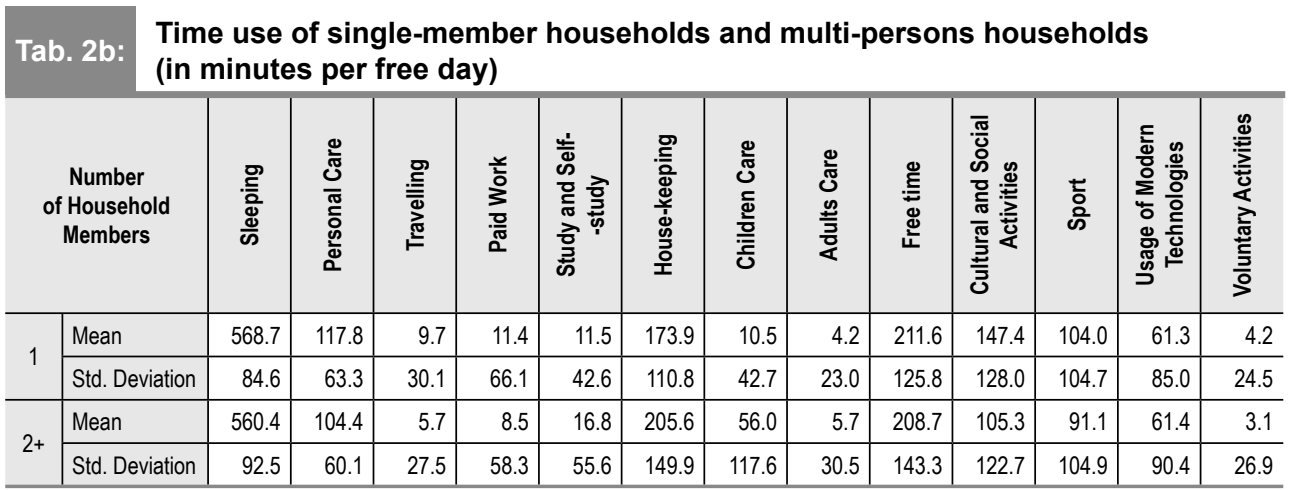




\subsection{Specific Features of Single-Member Households}

Single-member households have many specific features comparing to the multi-persons households. Among others, household's budget utilization, allocation of the time, time for work activities and life activities are significant. The same as other households, singlemember households must perform standard activities in the time not spending at work food preparation, housekeeping, pet care and others. However, extent and structure of these activities seems to be different than in multipersons households. There are many factors that influence extent of the time dedicated to daily activities. Most important are gender, age, place of living, income, health conditions, education, time spent in a paid job and others.

Tabs. $2 a$ and $2 b$ display time use of persons living alone and multi-persons households, both in working days and free days.

We calculated data for multi-persons households as average per household's members. Single-member households include only persons older than 18 years of age. To assure comparability of data, we excluded from multi-persons households persons younger than 18 years of age. It allows us to eliminate time use of adolescent, who usually do not participate on labour market and tend to avoid any unpaid work at the household.
Persons in single-member households spend in average 32 minutes per day more time in paid work than persons in multi-persons households during the working days. During the free days, they also spend more time by paid work (approximately 3 minutes per day more than persons in multi-person households). Persons in single-member households, on the other side, spend much more time by cultural and social activities (in working day two times more time and in free days 42 minutes more than member of multi-persons households). Members of multi-person households dedicate significantly more time to unpaid work activities, mostly to childcare, and to study and self-study.

The following graph in Fig. 1 displays comparison of aggregated time of groups of activities of single-member households and multiple-members households, in working day and in free day. We aggregated paid activities and travelling (travelling in our research corresponds mostly with traveling to work and from work), leisure time activities (this group includes free time, cultural and social activities, sport, and usage of modern technologies), and unpaid work (it includes house-keeping, children care and adults care). Last four groups of activities (personal care, sleeping, study and self-study, and voluntary activities) rest unattached.

\section{Fig. 1: Comparison of time use of single-member households and multi-persons households (in minutes per day and person)}

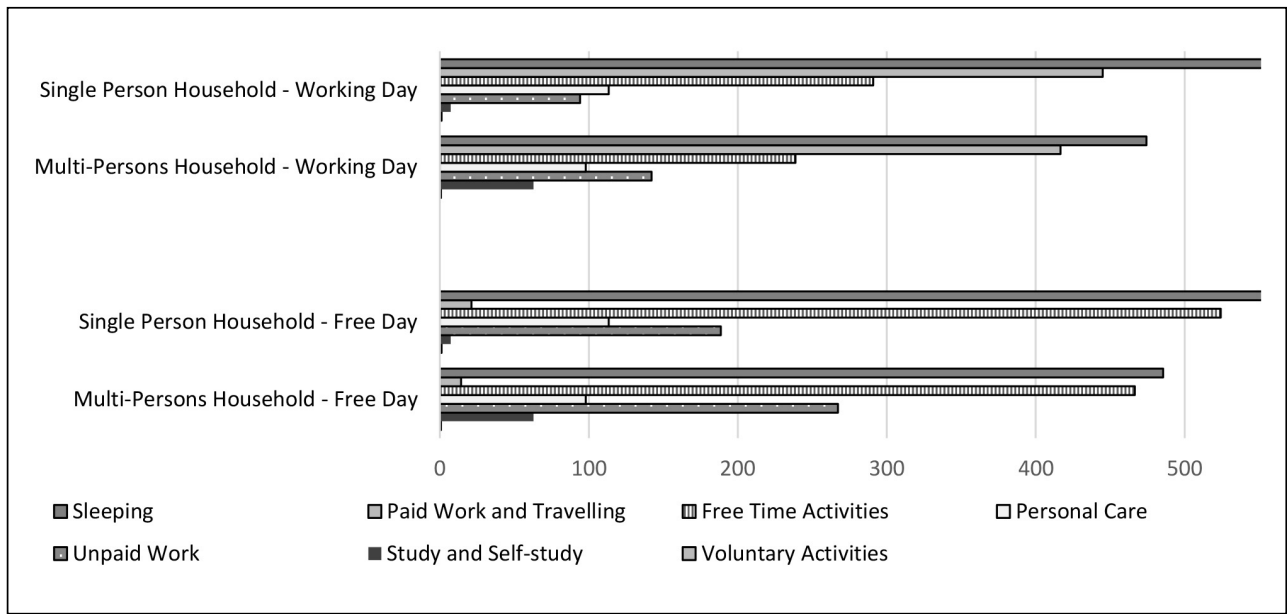




\section{Ekonomie}

\subsection{The Time Use of Single-Member Households by Gender}

Gender and age belong to the most important factors influencing allocation of the time of persons during the day (Loretto \& Vickerstaff,
2015; Allen \& Finkelstein, 2014; Dex \& Bond, 2005; Higgins et al., 1994).

In Tabs. 3a and 3b, there is the time use of men and female living alone during the working day and free day.

\section{Tab. 3a: \\ Time allocation of single-member households by gender (in minutes per working day)}

\begin{tabular}{|c|c|c|c|c|c|c|c|c|c|c|c|c|c|c|}
\hline & Gender & $\begin{array}{l}\frac{\text { Dे }}{\bar{a}} \\
\frac{\mathbb{\Phi}}{\omega}\end{array}$ & 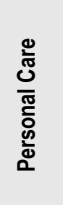 & 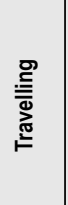 & 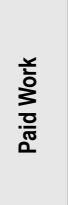 & 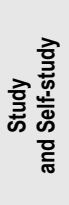 & 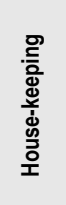 & 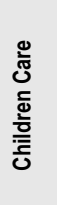 & 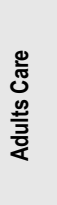 & 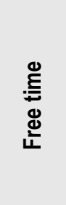 & 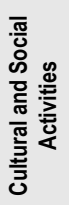 & $\begin{array}{l}\text { 흠 } \\
\text { की }\end{array}$ & 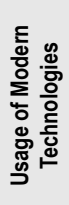 & 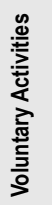 \\
\hline \multirow{2}{*}{ M } & Mean & 468.8 & 100.9 & 46.5 & 451.2 & 7.0 & 59.9 & 0.8 & 0.4 & 141.8 & 37.3 & 57.1 & 63.7 & 0.0 \\
\hline & Std. Deviation & 82.1 & 49.0 & 53.2 & 216.1 & 42.0 & 80.1 & 9.5 & 4.8 & 103.4 & 65.7 & 62.8 & 68.6 & 0.0 \\
\hline \multirow{2}{*}{$\mathrm{F}$} & Mean & 500.6 & 124.3 & 40.9 & 357.1 & 7.6 & 117.2 & 6.5 & 0.0 & 176.4 & 45.4 & 31.8 & 29.2 & 2.3 \\
\hline & Std. Deviation & 94.8 & 76.4 & 35.0 & 256.4 & 32.3 & 104.3 & 31.7 & 0.0 & 117.2 & 78.8 & 60.4 & 45.8 & 14.4 \\
\hline
\end{tabular}

Source: own

Note: $\mathrm{M}$ - male, $\mathrm{F}$ - female.

Tab. 3b:

Time allocation of single-member households by gender (in minutes per free day)

\begin{tabular}{|c|c|c|c|c|c|c|c|c|c|c|c|c|c|c|}
\hline \multicolumn{2}{|c|}{ Gender } & \multirow{2}{*}{ 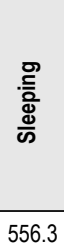 } & \multirow{2}{*}{ 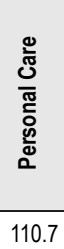 } & \multirow{2}{*}{ 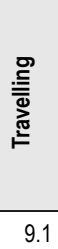 } & \multirow{2}{*}{ 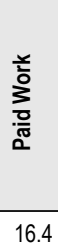 } & \multirow{2}{*}{ 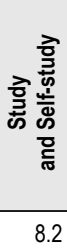 } & \multirow{2}{*}{ 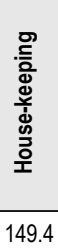 } & \multirow{2}{*}{ 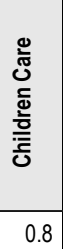 } & \multirow{2}{*}{$\begin{array}{l}\frac{0}{0} \\
\text { 心 } \\
\frac{9}{5} \\
\frac{5}{0} \\
< \\
6.1\end{array}$} & \multirow{2}{*}{ 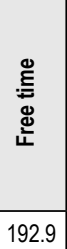 } & \multirow{2}{*}{ 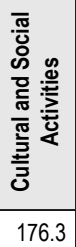 } & \multirow{2}{*}{$\begin{array}{l}\text { के } \\
\text { के } \\
125.4\end{array}$} & \multirow{2}{*}{ 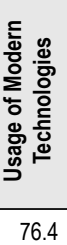 } & \multirow{2}{*}{ 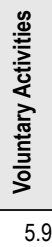 } \\
\hline \multirow{2}{*}{$M$} & Mean & & & & & & & & & & & & & \\
\hline & Std. Deviation & 89.5 & 56.5 & 24.3 & 80.0 & 29.3 & 123.3 & 9.5 & 28.8 & 116.8 & 138.2 & 106.9 & 87.3 & 32.0 \\
\hline \multirow{2}{*}{$F$} & Mean & 579.6 & 124.1 & 10.3 & 7.0 & 14.4 & 195.7 & 19.2 & 2.4 & 228.2 & 121.7 & 84.9 & 47.9 & 2.7 \\
\hline & Std. Deviation & 78.7 & 68.4 & 34.5 & 50.6 & 51.6 & 93.6 & 56.7 & 16.2 & 131.5 & 112.5 & 99.2 & 81.0 & 15.0 \\
\hline
\end{tabular}

Source: own

Note: $\mathrm{M}$ - male, $\mathrm{F}$ - female.

By the mean of non-parametric test (MannWhitney test), we tested statistically significant differences between the extent of time that men and females dedicate per various activities during the working days and free days. During the working day, there are statistically significant differences in the extent of time dedicated for sleeping, personal care, children care and free time (females spend more time by these activities than men; p-values: 0.013 ; $0.007 ; 0.024 ; 0.026)$, and housekeeping (women spend double time by housekeeping in working days than men; $p$-value $=0$ ). On the other side, men spend significantly more time during the working day in paid work (almost 95 minutes per day more than women; $p$-value $=$ 0.006 ), by performing sport activities (almost double time than women) and by using modern technologies (more than double time than women; $p$-value $=0$ ).

During the free days, statistically significant differences are in housekeeping, children care 
and free time (women spend more time by performing these activities than men) and in sport activities, usage of modern technologies and cultural and social activities (men spend more time by performing these activities than women). During the free day, women tend to sport almost three times more than during the working days and use modern technologies almost 20 minutes more than in working days; however, it is still significantly less than in case of men. On the other side, men do housekeeping almost 150 minutes per day in free day (comparing to about 59 minutes in working days). It is, however, significantly less than in case of women (117 minutes in working days and almost 196 minutes in free days). It is interesting, that men are significantly more involved in cultural and social activities during the free days than women (men 176 minutes per day, women only 112 minutes per day).

Besides quantitative analysis we partly focused on qualitative analysis. Questions from the questionnaire from our field research allowed us deeper analysis of opinions of respondents towards the relationship between the paid work and unpaid work. We asked individuals five questions regarding their opinions. In Tab. 4, there are frequencies of attitudes (respondents can either agree, or disagree, or has not thought about it) towards five statements, divided by gender.

By the means of Mann-Whitney $U$ test we tested, whether there are statistically significant differences in the attitudes of men and women. We found out, that there are no statistically significant differences ( $p$-values: $0.704 ; 0.753 ; 0.159 ; 0.110 ; 0.337$ ). As following step, we tried to find out, whether there are significant differences in attitudes towards various statements (in this test, we did not distinguish respondents by gender). By the means of Friedman and Wilcox test, we verified there is a statistically significant difference only in second statement. It means singlemember households expressed the strongest disagreement with increasing the volume of their unpaid work at the expense of their paid work $(p$-value $=0)$.

\subsection{The Time Use of Single-Member Households by Age}

Regarding the structure of single-member households according to age, we focused on two the most important groups - young persons to 30 years of age and elderly persons above the 65 years. Tabs. $5 \mathrm{a}$ and $5 \mathrm{~b}$ display the time use of single-member households by the age

\section{Tab. 4: \\ Attitudes of single-member households by gender on paid work and unpaid work relations}

\begin{tabular}{|c|c|c|c|c|c|c|c|c|c|c|c|c|}
\hline & \multicolumn{6}{|c|}{ Men } & \multicolumn{6}{|c|}{ Women } \\
\hline & \multicolumn{2}{|c|}{ I disagree } & \multicolumn{2}{|c|}{ I agree } & \multicolumn{2}{|c|}{$\begin{array}{l}\text { I have } \\
\text { no thought } \\
\text { about it }\end{array}$} & \multicolumn{2}{|c|}{ I disagree } & \multicolumn{2}{|c|}{ I agree } & \multicolumn{2}{|c|}{$\begin{array}{l}\text { I have } \\
\text { no thought } \\
\text { about it }\end{array}$} \\
\hline & Count & Row \% & Count & Row \% & Count & Row \% & Count & Row \% & Count & Row \% & Count & Row \% \\
\hline $\begin{array}{l}\text { I would like to increase the } \\
\text { volume of my paid work at } \\
\text { the expense of my unpaid } \\
\text { work }\end{array}$ & 57 & .455 & 46 & .370 & 22 & .175 & 43 & .337 & 42 & .326 & 43 & .337 \\
\hline $\begin{array}{l}\text { I would like to increase the } \\
\text { volume of my unpaid work at } \\
\text { the expense of my paid work }\end{array}$ & 84 & .657 & 18 & .143 & 26 & .201 & 75 & .598 & 12 & .092 & 39 & .310 \\
\hline $\begin{array}{l}\text { I would like to keep my } \\
\text { current volume of both paid } \\
\text { and unpaid work }\end{array}$ & 31 & .245 & 70 & .549 & 26 & .206 & 25 & .203 & 69 & .555 & 30 & .242 \\
\hline $\begin{array}{l}\text { I would like to have more } \\
\text { free time by having less } \\
\text { paid work }\end{array}$ & 52 & .421 & 39 & .310 & 33 & .269 & 59 & .463 & 31 & .245 & 37 & .291 \\
\hline $\begin{array}{l}\text { I would like to have more } \\
\text { free time by having less } \\
\text { unpaid work }\end{array}$ & 39 & .315 & 50 & .403 & 35 & .281 & 34 & .272 & 49 & .389 & 43 & .339 \\
\hline
\end{tabular}




\section{Ekonomie}

Tab. 5a:

The time use of single-member households by age (in minutes per working day)

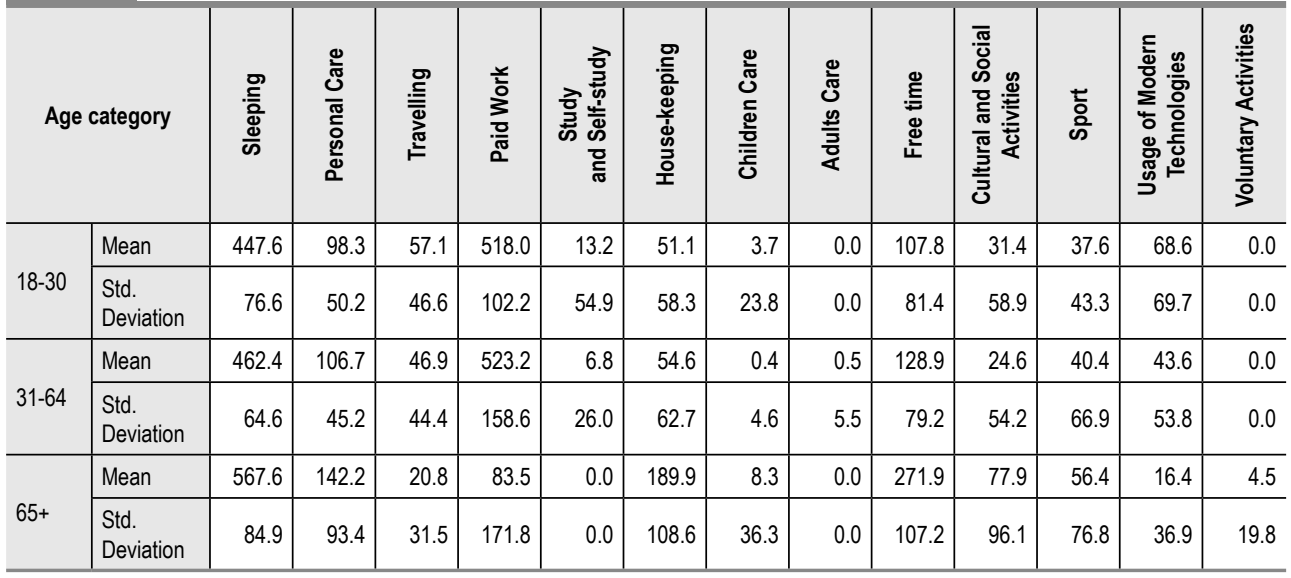

Source: own

Tab. 5b:

The time use of single-member households by age (in minutes per free day)

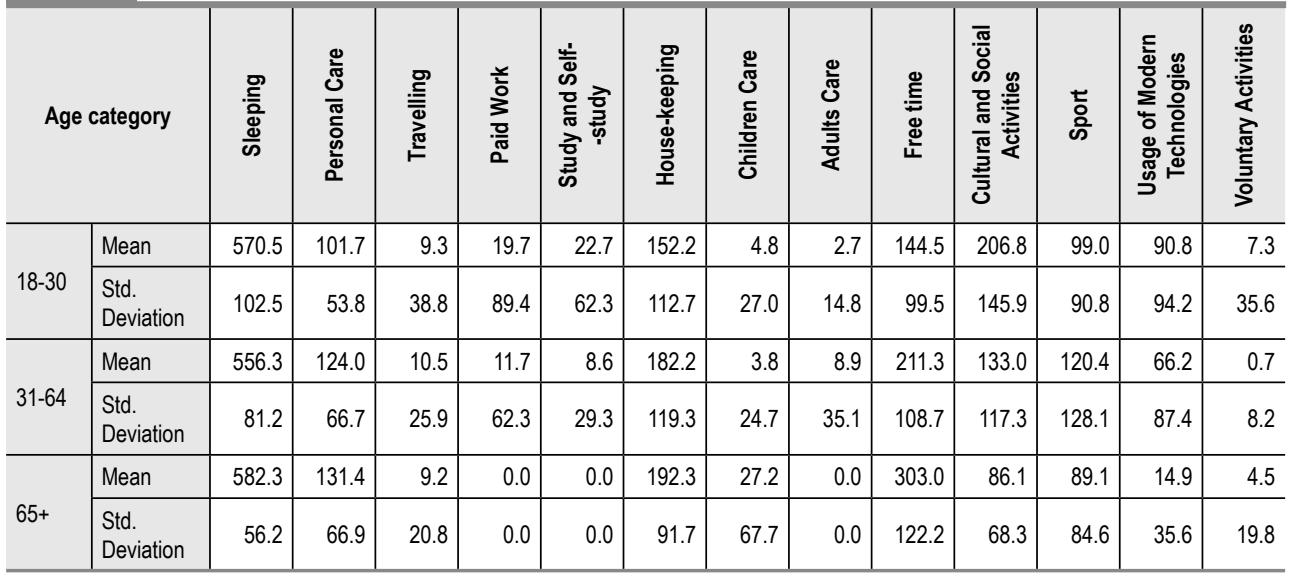

Source: own

groups (in the tables there are data for all three age groups, from 18 up to 30 , between 30 and 64 , and over 65 years of age).

When we compared time that young persons living alone spend in paid work with the average time that persons in single-member households and persons in multi-person households spend in paid work, we found out significant differences. Young persons living alone spend in average 518 minutes (it means 8 hours and 38 minutes) per working day in paid work, while average time of members of single person households in paid work is 401 minutes (it means 6 hours and 41 minutes) per working day and members of multi-persons households only 369 minutes (it means 6 hours and 9 minutes).

By the mean of non-parametric test (MannWhitney test), we tested statistically significant differences between the extent of time that persons between 18 and 30 and persons older than 65 dedicate to various daily activities. Young persons spend significantly more time by paid work, travelling, study and self-study, 
and usage of modern technologies during the working day (all p-values $=0$ ). It is not a surprising result, because persons over 65 years of age belong to the post-productive group in Slovakia and participate actively on labour market (or run own entrepreneurial activities) only rarely. Also using of modern technologies is a domain of younger generation. On the other side, persons over 65 spend significantly more time during the working days by sleeping, personal care, housekeeping, free time, cultural and social activities (all p-values $=0$ ). The situation is very similar also during the free days. The only one change is in cultural and social activities (during the free days, young persons spend significantly more time by these activities than older persons; $p$-value $=0$ ).

We analysed also attitudes of persons (in age group to 30 years and over 65 years of age) on the extent of paid work and unpaid work and their mutual relations. In case of persons over 65 , most of the answers were "I have no thought about it". It is not surprising, because persons over 65 usually do not participate actively on labour market and most of their answers were indifferent towards the paid work - unpaid work relation. It means, there is no reason to analyse deeper their attitudes towards time dedicated to paid and unpaid work, and we focused only on the analysis of the attitudes of young persons living alone (between 18 and 30 years of age).
Frequencies of answers of young persons living alone (I agree, I disagree, or I have not thought about it) are displayed in Tab. 6.

Respondents (young persons living alone, in the age between 18 and 30 ) expressed the strongest disagreement with increasing the volume of their unpaid work at the expense of their paid work.

\subsection{Correlation Analysis}

We carried out Spearman correlation to examine patterns of relationships between the gender, age, education, paid work, and unpaid work. Based on the study of Aguiar et al. (2013) and his findings about the single-member households and extent of the unpaid domestic work, we test the correlation between the age, gender, education, paid work, and unpaid work performed by single-member households. Tab. 7 displays Spearman's correlations between the age, gender, education, and unpaid work performed by single-member households in working days and in free days. Correlations were tested on the significance level $\alpha=0.05$.

The relationships between the variables shown in Tab. 7 indicate positive correlation between the gender and unpaid work (performed both in working days and free days) and between the age and unpaid work (performed both in working days and free days). It means, that we confirmed that female

\begin{tabular}{|c|c|c|c|c|c|c|}
\hline \multirow[t]{4}{*}{ Tab. 6: } & nber $h$ & useho & s on $\mathrm{p}$ & work & & \\
\hline & \multicolumn{6}{|c|}{ Age category $18-30$} \\
\hline & \multicolumn{2}{|c|}{ I disagree } & \multicolumn{2}{|c|}{ I agree } & \multicolumn{2}{|c|}{$\begin{array}{l}\text { I have no thought } \\
\text { about it }\end{array}$} \\
\hline & Count & Row \% & Count & Row \% & Count & Row \% \\
\hline $\begin{array}{l}\text { I would like to increase the volume of my } \\
\text { paid work at the expense of my unpaid } \\
\text { work }\end{array}$ & 36 & 0.386 & 41 & 0.440 & 16 & 0.174 \\
\hline $\begin{array}{l}\text { I would like to increase the volume of my } \\
\text { unpaid work at the expense of my paid } \\
\text { work }\end{array}$ & 66 & 0.708 & 9 & 0.099 & 18 & 0.193 \\
\hline $\begin{array}{l}\text { I would like to keep my current volume } \\
\text { of both paid and unpaid work }\end{array}$ & 28 & 0.298 & 52 & 0.552 & 14 & 0.149 \\
\hline $\begin{array}{l}\text { I would like to have more free time } \\
\text { by having less paid work }\end{array}$ & 42 & 0.450 & 35 & 0.372 & 17 & 0.177 \\
\hline $\begin{array}{l}\text { I would like to have more free time } \\
\text { by having less unpaid work }\end{array}$ & 30 & 0.326 & 43 & 0.469 & 19 & 0.206 \\
\hline
\end{tabular}




\begin{tabular}{l|l|r|r|r|r|r}
\multicolumn{2}{c|}{} & $\begin{array}{c}\text { Unpaid } \\
\text { work } \\
\text { (working } \\
\text { day) }\end{array}$ & $\begin{array}{c}\text { Unpaid work } \\
\text { (free day) }\end{array}$ & Age & Education & Gender \\
\hline $\begin{array}{l}\text { Unpaid work } \\
\text { (working day) }\end{array}$ & $\begin{array}{l}\text { Correlation } \\
\text { Coefficient }\end{array}$ & 1 & 0.311 & 0.426 & -0.393 & 0.282 \\
\cline { 2 - 7 } & Sig. (2-tailed) &. & 0.000 & 0.000 & 0.000 & 0.000 \\
\hline $\begin{array}{l}\text { Unpaid work } \\
\text { (free day) }\end{array}$ & $\begin{array}{l}\text { Correlation } \\
\text { Coefficient }\end{array}$ & 0.311 & 1 & 0.207 & -0.188 & 0.234 \\
\cline { 2 - 7 } & Sig. (2-tailed) & 0.000 & & 0.000 & 0.001 & 0.000 \\
\hline
\end{tabular}

living alone perform more unpaid work than men living alone. We also confirmed, that extent of unpaid work is increasing with the age of persons living alone. On the other side, there is a negative correlation between the education and extent of unpaid work (performed both in working days and free days). It means, higher the education of person living alone, lower the extent of unpaid work he/ she performs.

Using the Spearman's correlations, we also analysed correlations between the extent of paid work and unpaid work of single-members households. Spearman's correlations confirmed negative correlation between the extent of paid work (during the working day) and extent of unpaid work (during the working day). It means, more the time person living alone spends in paid work, less the unpaid work he/she performs.

\section{Conclusions and Discussion}

This study focuses on the time use of persons living alone in single-member households. These persons live out of standard family, without children (it does not mean that they do not have children). To analyse time use of single-member households, we used data from our unique research, which was conducted in Slovak households in 2017. We used data on time use collected by the means of household member diary. Together, 301 single-member households were included in our research.

\section{Main Findings of the Study}

The aim of this study was to examine the time use of single-member households in Slovakia. We focused on single-member households because they represent continually growing group of households not only in Slovakia, but also in the whole western world. According to last census (from 2011), single-member households represent $25.7 \%$ of all households in Slovakia (when considering census households, it is $29.5 \%$ of all households). According to the Prognóza vývoja rodín a domácností na Slovensku do roku 2030, growing trend of single-member households will continue also in the future.

We found out that single-member households in Slovakia spend more time in paid work than multi-persons households. Persons living alone also tend to spend more time by cultural and social activities, sport, and usage of modern technologies than persons living in the multiple-members households. This is in accordance with the results of Hawk research (2011). We did not focus on how much money persons spend for these activities, we focused only on the volume of spent time.

Within the single-member households, we analysed and compared particular groups of persons: men and women, and persons younger than 30 years of age and persons over 65 years of age. Gender inequality in paid work and unpaid work (including children care) was documented by several studies (Emslie \& Hunt, 2008; Smithson \& Stokoe, 2005; Uramová \& Orviská et al., 2016). We confirmed, that time use of men living alone is different than time use of women living alone. We found out, that during the working days, women spend significantly more time by sleeping, personal care, housekeeping, children care and free time than men. Men, on the other side, spend more time in paid work and by sport and usage 
of modern technologies. During the free days, there are significant differences by gender in housekeeping, children care, and free time (women spend more time by these activities than man) and in cultural and social activities, usage of modern technologies and sport (men spend more time by performing these activities than women).

Young persons living alone (between 18 and 30 years of age) belong very often to the group of "singles" (Jamieson \& Simpson, 2013; Beck \& Beck-Gernsheim, 2002; Poortman \& Liefbroer, 2010). Besides other characteristics, they tend to have different approach to work than persons living in family structure. We confirmed that young persons living alone spend significant part of their daily activities by paid work (more than 8 and half hours per working day). It is almost 2 hours more than an average for single-member households and almost 2 and half hours more than an average for person in multi-persons households. It would mean, besides other implications, that employers would have an incentive to hire young singles and to discriminate against multipersons household members.

Single-member households with persons over 65 years of age are another specific group of single-member households. Most of them were living in the traditional family structures in the past (they live alone mostly because they are divorced or widowed). Because they do not participate actively on labour market any more, their daily time use is significantly different from the daily time use of young persons in productive age.

In the study, we also tested correlation between the age, gender, education, paid work, and unpaid work performed by single-member households (based on the study of Aguiar et al., 2013). We confirmed positive correlation between the gender and unpaid work, and between the age and unpaid work. We found out that there is a negative correlation between the education and extent of unpaid work, and between the extent of paid work and extent of unpaid work (this is valid during the working days).

\section{Meaning and Implications of the Findings}

The study implies that single-member households in Slovakia are becoming important agents and they are special also because of the specific allocation of the time during the working days and free days. Most of the time use concepts focus on the persons living in family structures (married or unmarried couples, with or without children). There are no reasonable foreign studies focusing on the time use of person living alone in singlemember households. Even more, in Slovakia there are no any studies about the time use of households in general, because time use survey have not been launched in Slovakia, yet. Our study offers unique data, based on the original field research on time use of Slovak households and individuals.

In the study, we examined daily time use of persons living alone in single-member households and allocation of their daily time on thirteen activities. There are, however, several limitations of our research and findings. It was the first survey focusing on use of time of households that was realised in Slovakia. It will be necessary to repeat the survey in regular intervals to confirm our findings and to identify trends and changes in the use of time of singlemember households. Data from our research can be used not only for comparison of daily time use and time distribution in specific groups of households (in case of this article, in singlemember households), but also for analysing work-life balance, decisions about the time allocation and understanding well-being of individuals and households. We consider necessary to continue with our research and to extend our research (questionnaire) with questions, which will allow us to analyse also qualitative approach towards the work-life balance and well-being. It will be also interesting to compare results of our research with situation in other countries, however, available data sources do not allow us deeper analysis of use of time of single-member households abroad.

Results of our research, particularly results included in this study, can serve as unique source of information for marketers (singlemember households tend to spend more time by leisure time activities, such as social and cultural activities, sport and using modern technologies, than members of multiple-member households. That is why specific portfolio of products and services corresponding with their specific interests can be offered to them); companies (we confirmed, that persons living alone, mostly men, spend more time by paid activities than other groups of persons. This information can be interesting for employers or potential employers 
of persons living alone, mostly regarding of possible over-time work); goods and services providers (we confirmed, that persons living alone spend less time by unpaid work than members of multiple-members households. They are also not willing to reduce their paid work for the benefit of unpaid work. That is why companies can offer market substitutes of unpaid work activities to them, to reduce the extent time for unpaid work even more). Results can also serve as fundament for public policies actions. Singlemember households (mostly young persons) tend to spend significant part of their leisure time by sport, usage of modern technologies and by cultural activities. Growing number of persons living alone demand more sport facilities, more cultural occasions, and more possibilities for active leisure time in general. Ratio of persons over 65 years of age living alone is growing and it will be necessary to focus also on their daily time use. We found out that they spend only limited time by using modern technologies and by social and cultural activities and sport. This could lead to the social isolation of this specific group of single-member households. Even more, time for studying and self-studying is absenting within their daily time use at all. We consider inevitable, that in case of persons over 65 living alone, state and state institutions should launch initiatives to support socialization, further education and eventually also labour market participation of this group of persons.

This paper is an output of scientific project of Grant Agency VEGA no. No.1/0621/17 "Decision-making Process of Slovak Households about Allocation of Time for Paid and Unpaid Work and Household Strategies' Impact on Selected Areas of the Economic Practice" at the Faculty of Economics, Matej Bel University in Slovakia."

\section{References}

Aguiar, M., Hurst, E., \& Karabarbounis, L. (2013). Time use during the great recession. American Economic Review, 103(5), 1664-1696. https://dx.doi.org/10.1257/ aer.103.5.1664.

Bailyn, L., Drago, R., \& Kochan, T. A. (2001). Integrating Work and Family Life. A Holistic Approach. A Report of the Sloan Work-Family Policy Network. Retrieved December 12, 2017, from http://web.mit.edu/workplacecenter/docs/ WorkFamily.pdf.
Beck, U., \& Beck-Gernsheim, E. (2010). The normal chaos of love. Cambridge: Polity Press.

Bittman, M., \& Wajcman, J. (2000). The rush hour: The Character of Leisure Time and Gender Equity. Social Forces, 79(1), 165-189. https://dx.doi.org/10.1093/sf/79.1.165.

Bonke, J. (2005). Paid work and unpaid work: Diary information versus questionnaire information. Social Indicators Research, 70(3), 349-368. https://dx.doi.org/10.1007/s11205-0041547-6.

Bruvoll, A., Halvorsen, B., \& Nyborg, K. (2002). Households' recycling efforts. Resources, Conservation and Recycling, 36(4), 337-354.

Budlender, D. (Ed.). (2010). Time use studies and unpaid care work. New York: Routledge.

Caproni, P. J. (1997). Work/Life Balance. You can't Get there from here. The Journal of Applied Behavioral Science, 33(1), 46-56. https://dx.doi.org/10.1177/0021886397331003.

Centre for Comparative Social Surveys. (2010). Source Questionnaire Final (Round 5, 2010/11). London: Centre for Comparative Social Surveys, City University London. Retrieved December 10, 2017, from http://europeansocialsurvey.org/docs/round5/ fieldwork/source/ESS5_source_main_ questionnaire.pdf.

Craig, L. (2006). Does father care mean fathers share? A comparison of how mothers and fathers in intact families spend time with children. Gender \& society, 20(2), 259-281. https://dx.doi.org/10.1177/0891243205285212.

Dex, S., \& Bond, S. (2005). Measuring work-life balance and its covariates. Work, Employment and Society, 19(3), 627-637. https://dx.doi.org/10.1177/0950017005055676.

Dudová, R. (Ed.). (2008). Nové šance a rizika. Flexibilita práce, marginalizace a soukromý život u vybraných povolání a sociálních skupin. Praha: Sociologický ústav Akademie věd ČR.

Emslie, C., \& Hunt, K. (2008). 'Live to Work' or 'Work to Live'? A Qualitative Study of Gender and Work-life Balance among Men and Women in Mid-life. Gender, Work \& Organization, 16(1), 151-172. https://dx.doi.org/10.1111/j.14680432.2008.00434.x.

European Communities. (2009). Harmonized European time use surveys. 2008 guidelines. Luxembourg: Office for Official 
Publications of the European Communities. Retrieved October 19, 2017, from http://ec.europa.eu/eurostat/ramon/statmanuals/ files/KS-RA-08-014-EN.pdf.

Greenhaus, J. H., \& Singh, R. (2003). Work-family linkages, A Sloan work and family encyclopedia entry. Retrieved December 10, 2017, from http://wfnetwork.bc.edu/ encyclopaedia_entry.php?id=263\&area=All.

Hawk, W. (2011). Household spending by single persons and married couples in their twenties: a comparison. Consumer Expenditure Survey Anthology (pp. 40-46). Retrieved December 12, 2017, from https://www.bls.gov/ cex/anthology11/csxanth6.pdf.

Higgins, C., Duxbury, L., \& Lee, C. (1994). Impact of Life-Cycle Stage and Gender on the Ability to Balance Work and Family Responsibilities. Family Relations, 43(2), 144150. https://dx.doi.org/10.2307/585316.

Hill, C. R., \& Stafford, F. P. (1980). Parental care of children: Time diary estimates of quantity, predictability, and variety. Journal of Human Resources, 15(2), 219-239. https://dx.doi.org/10.2307/145332.

Hill, E. J., Hawkins, A. J., Ferris, M., \& Weitzman, M. (2001). Finding an Extra Day a Week: The Positive Influence of Perceived Job Flexibility on Work and Family Life Balance. Family Relations, 50(1), 49-58. https://dx.doi. org/10.1111/j.1741-3729.2001.00049.x.

Hodgson, A. (2007). One-Person Households: Opportunities for Consumer Good Companies. Retrieved February 10, 2018, from https://blog.euromonitor.com/2007/09/ one-person-households-opportunities-forconsumer-goods-companies.html.

Hooper, A., Dunmore, K., \& Hughes, M. (1998). Home Alone: The Housing Preferences of One-person Households. Amersham: National House Building Council.

Hook, J. L. (2006). Care in context: Men's unpaid work in 20 countries, 1965-2003. American sociological review, 71(4), 639-660. https://dx.doi.org/10.1177/000312240607100406.

Jamieson, L., \& Simpson, R. (2013). Living Alone: Globalization, Identity and Belonging. New York: Palgrave Macmillan.

Jin-woong Son, Hyun-cheol Seo, \& Wonhwa Hong. (2016). A Study on the living behavior of Single-household in University Town through the Questionnaire survey. Advanced Science and Technology Letters, (124), 93-97. https://dx.doi.org/10.14257/astl.2016.124.19.
Kalenkoski, C. M., Ribar, D. C., \& Stratton, L. S. (2005). Parental child care in single-parent, cohabiting, and marriedcouple families: Time-diary evidence from the United Kingdom. American Economic Review, 95(2), 194-198. https://dx.doi. org/10.1257/000282805774670176.

Kaufmann, J.-C. (1999). La Femme Seule et Le Prince Charmant. Paris: Nathan.

Kitamura, R., Fujii, S., \& Pas, E. (1997). Time-use data, analysis and modeling: toward the next generation of transportation planning methodologies. Transport Policy, 4(4), 225-235. https://dx.doi.org/10.1016/S0967070X(97)00018-8.

Klinenberg, E. (2012). Going solo: The extraordinary rise and surprising appeal of living alone. New York: Penguin Press.

Lewis, S., \& Cooper, C. (2005). Work-life Integration. Case Studies of Organisational Change. Chichester: Wiley.

Loretto, W., \& Vickerstaff, S. (2015). Gender, age and flexible working in later life. Work, Employment and Society, 29(2), 233-249. https://dx.doi.org/10.1177/0950017014545267.

Mankiw, N. G. (1999). Zásady ekonomie. Praha: Grada Publishing.

Nässén, J., \& Larsson, J. (2015). Would shorter working time reduce greenhouse gas emissions? An analysis of time use and consumption in Swedish households. Environment and Planning C: Politics and Shape, 33(4), 726-745. https://dx.doi. org/10.1068/c122392015.

Nie, N. H., Hillygus, D. S., \& Erbring, L. (2002). Internet use, interpersonal relations, and sociability: A time diary study. In B. Wellman, \& C. Haythornthwaite (Eds.), The Internet in Everyday Life (pp. 213-243). Oxford: Blackwell Publishers Ltd.

Poortman, A.-R., \& Liefbroer, A. C. (2010). Singles' relational attitudes in a time of individualization. Social Science Research, 39(6), 938-949. https://dx.doi.org/10.1016/j. ssresearch.2010.03.012.

Robinson, J., \& Godbey, G. (1997). Time for Life: The Surprising Ways Americans Use Their Time. University Park, PA: Pennsylvania State University Press.

Roseneil, S., \& Budgeon, S. (2004). Cultures of Intimacy and Care beyond the Family: Personal Life and Social Change in the Early 21st Century. Current Sociology, 2(2), 135-159. https://dx.doi.org/10.1177/0011392104041798. 
Samuelson, P. A., \& Nordhaus, W. D. (Eds.). (2013). Ekonomie. Praha: NS Svoboda.

Sevilla-Sanz, A., Gimenez-Nadal, J. I., \& Fernández, C. (2010. Gender roles and the division of unpaid work in Spanish households. Feminist Economics, 16(4), 137-184. https://dx.doi.org/10.1080/13545701.2010.531197.

Seybert, H. (2011). Internet use in households and by individuals in 2011. Eurostat statistics in focus. Retrieved December 10, 2017, from http://ec.europa. eu/eurostat/documents/3433488/5579964/KSSF-11-066-EN.PDF/090e071f-c3a9-45d8-aa909b142251fd3a.

Singly, F. (2009). Mít vlastní pokoj. Ke vztahu mezi prostorem a osobní identitou. Sociálni Studia/Social Studies, 6(4), 13-22.

Smithson, J., \& Stokoe, E. H. (2005). Discourses of Work-Life Balance: Negotiating 'Genderblind' Terms in Organizations. Gender, Work \& Organization, 12(2), 105-191. https:// dx.doi.org/10.1111/j.1468-0432.2005.00267.x.

Robinson, J. P., Converse, P. E., \& Szalai, A. (1972). The use of time: Daily activities of urban and suburban populations in twelve countries. Den Haag: Mouton.

Šprocha, B., Vaňo, B., \& Bleha, B. (2014). Prognóza vývoja rodín a domácností na Slovensku do roku 2030. Bratislava: Ekonóm.

Šprocha, B., \& Bleha, B. (2015). Geografické a demografické determinanty regionálnej diferencovanosti cenzových domácností na Slovensku - analýza a prognóza do roku 2030. Geografický časopis, 67(3), 219-241.

Tammy, A. D., \& Finkelstein, L. M. (2014). Work-family conflict among members of fulltime dual-earner couples: An examination of family life stage, gender, and age. Journal of Occupational Health Psychology, 19(3), 376-384. https://dx.doi.org/10.1037/a0036941.

Uramová, M., \& Orviská, M., et al. (2016). Neplatená práca na Slovensku. Banská Bystrica: Belianum.

Zist'ovanie o využívaní času. Metodická štúdia. Sekcia sociálnych štatistík a demografie. Odbor štatistiky životnej úrovne obyvatel'stva. Štatistický úrad SR.
Wang, Y. (2006). The analysis of modern Chinese family structure. Chinese Social Science, 1, 96-108.

Widén, J., et al. (2009). Constructing load profiles for household electricity and hot water from time-use data-Modelling approach and validation. Energy and Buildings, 41(7), 753-768. https://doi.org/10.1016/j. enbuild.2009.02.013.

Williams, J. (2003). Homes for the Future - A Means for Managing the Singletons' Consumption Crisis? London: University College.

Wittenberg, M., Collinson, M., \& Harris, T. (2017). Decomposing changes in household measures: Household size and services in South Africa, 1994-2012. Demographic research, 37(39), 1297-1326. https://dx.doi. org/10.4054/DemRes.2017.37.39.

Wulff, M. (2001). Growth and change in one person households: Implications for the housing market. Urban Policy and Research, 19(4), 467-489. https://dx.doi. org/10.1080/08111140108727894.

Zhan Hu, \& Xizhe Peng. (2015). Household changes in contemporary China: an analysis based on the four recent censuses. The Journal of Chinese Sociology, 2(9). https://dx.doi. org/10.1186/s40711-015-0011-0.

Ing. Mgr. Miroslava Knapková, Ph.D. Matej Bel University Faculty of Economy Department of Economics Slovakia miroslava.knapkova@umb.sk

Ing. Alena Kaščáková, Ph.D. Matej Bel University Faculty of Economy Department of Quantitative Methods and Information Systems Slovakia alena.kascakova@umb.sk 


\section{Abstract}

\section{USE OF TIME IN SINGLE-MEMBER HOUSEHOLDS IN SLOVAKIA}

\section{Miroslava Knapková, Alena Kaščáková}

Households represent one of the basic units in economy. In the last years, the increasing number of single-member households has become a significant issue in Slovakia. In 2011, ratio of singlemember households was more than 25\% in Slovakia (The 2011 Population and Housing Census in Slovakia). It is an interesting phenomenon influencing not only labor market (paid work), but also unpaid work activities (work performed in households) and spending of the leisure time.

The aim of this study was to examine the time use of single-member households in Slovakia. We analyzed 301 single-member households and allocation of their daily time into 13 activities. To get information about the daily time use of persons, we used household member diary. Study offers unique data, based on the original field research on time use of Slovak households and individuals, which was conducted in 2017 by team of researchers from Faculty of Economics, Matej Bel University in Slovakia. Besides collecting data on time use, we also collected information about the attitudes and preferences of individuals concerning the paid work and unpaid work. Within the single-member households, we analyzed and compared specific groups of persons - men and women, and persons younger than 30 years of age and persons over 65 years of age.

We found out, that young persons living alone spend significant part of their daily activities by paid work (almost 2 and half hours more than an average for person in multi-persons households). Men living alone spend significant part of their daily time in paid work and by sport and usage of modern technologies. Time use of persons over 65 years living alone pointed to problem of their social isolation and absence of education in this age group.

Key Words: Time use, single-member households, Slovakia, time diary, unpaid work, paid work, leisure time.

JEL Classification: J14, J16, J22, D13.

DOI: 10.15240/tul/001/2018-3-003 